\title{
Hot Cracking of Metal Inert Gas Arc Welded Magnesium Alloy AZ91D
}

\author{
De Xin SUN, ${ }^{1,2)}$ Da Qian SUN, ${ }^{1)}$ Xiao Yan GU ${ }^{11}$ and Zhao Zhi XUAN ${ }^{11}$ \\ 1) Key Laboratory of Automobile Materials, Ministry of Education, and Department of Materials Science and Engineering, Jilin \\ University, No. 5988 Renmin Street, Changchun, 130025, P. R. China. E-mail: xuanzz@jlu.edu.cn \\ 2) The Amour Technology Institute of PLA, No. 1 Huayuan Road, Changchun, 130117, P. R. China.
}

(Received on July 7, 2008; accepted on November 4, 2008)

\begin{abstract}
The microstructure and cracking characteristics of MIG welded magnesium alloy (AZ91D) joint, and the effect of welding speed on cracking susceptibility have been investigated. The welded joint consists of primary $\alpha$-Mg and divorced phases (eutectic $\alpha$-Mg+eutectic $\beta$ - $\mathrm{Mg}_{17} \mathrm{Al}_{12}$ ), the latter mainly distributing along the $\alpha$-Mg grain boundaries. Solidification cracking often occurred in the crater and was also observed at weld center line when welding speed was $300 \mathrm{~mm} / \mathrm{min}$, which are associated with segregation of $\mathrm{Mn}, \mathrm{Al}$ and $\mathrm{Zn}$ and high tensile stresses in the welds. Liquation cracking appeared in HAZ immediately adjacent to the fusion line when low welding speed was used $(300 \mathrm{~mm} / \mathrm{min})$. It is mainly related to the low welding speed resulting in increasing heat input and tensile stresses in the HAZ. It is favorable to decrease heat input for improving the susceptibility of hot cracking during MIG welding of magnesium alloys.
\end{abstract}

KEY WORDS: magnesium alloy AZ91D; MIG arc welding; solidification cracking; liquation cracking.

\section{Introduction}

Magnesium alloys have low density, high specific strength and excellent recyclability, and have gained increased interest in a wide variety of applications. ${ }^{1-4)}$ Among the commercial magnesium alloys, AZ91D is widely used. ${ }^{5)}$ Besides the development of new alloy types, manufacturing techniques such as welding and joining play an important role in exploiting the new fields of applications.

There has been some research activity on welding of magnesium alloys in recent years. Various welding processes, principally laser beam welding, electron beam welding, tungsten inert-gas welding, friction stir welding, resistance spot welding and transient liquid phase bonding, were employed in the researches and many useful insights and data have been obtained. ${ }^{6-16)}$ Hot cracking is known as one of major problems in welding of magnesium alloys. ${ }^{17)}$ When cracking problems are encountered, it is important to be able to identify the type and characteristics of cracking so that the cause can be found and efficient remedial action taken. However, reports in published literature concerning cracking problems of welded magnesium alloy joints are limited. ${ }^{18,19)}$ This is because most of researchers used high energy density welding methods such as laser beam welding and electron beam welding, and thin magnesium alloy plates. Under these conditions, the welded joints have low cracking susceptibility due to low net heat input and degree of restraint causing relatively low tensile stress in the joints. For welding of relatively thick plates, metal inert gas (MIG) arc welding method is often used in engineering practice, so the welding stress and cracking susceptibility are ex- pected to be higher during welding of magnesium alloys.

The present work investigates the microstructure and cracking characteristics of MIG welded magnesium alloy (AZ91D) joints and the effect of welding speed on cracking susceptibility. Its purpose was to obtain better understanding of weldablity of magnesium alloys and provide some foundation for improving the susceptibility of cracking in welded magnesium alloy joints.

\section{Experimental Procedure}

In this investigation, as-cast AZ91D magnesium alloy test plates (base metal) with dimensions of $120 \mathrm{~mm} \times 80$ $\mathrm{mm} \times 10 \mathrm{~mm}$ and a magnesium alloy welding wire with the diameter of $1.6 \mathrm{~mm}$ were employed. The chemical compositions of the base metal and the welding wire are listed in Table 1.

MIG welding machine was used to weld the magnesium alloy plates in the form of butt joints. Prior to welding, a longitudinal single V-groove with $60^{\circ}$ angle and $8.4 \mathrm{~mm}$ in depth was machined on the test plates, and the oxidation, oil and dirt on surfaces of the test plates and welding wire were removed using the sand paper. The weld metal was deposited in the V-groove with Ar shielding gas, the welding parameters being welding current of $170 \mathrm{~A}$, welding voltage of $24 \mathrm{~V}$ and welding speeds of $300 \mathrm{~mm} / \mathrm{min}$ and $450 \mathrm{~mm} /$ min, respectively. After welding, the welded test plates cooled to room temperature in air. The welded joint specimens were cut down from the welded plates and were prepared by standard metallographic procedures. Microstructures and cracking characteristics of the welded joints were 
Table 1. Chemical compositions of base metal and welding wire (wt\%).

\begin{tabular}{lccccccccc}
\hline $\begin{array}{l}\text { Base metal } \\
\text { welding wire }\end{array}$ & and & $\mathrm{Al}$ & $\mathrm{Zn}$ & $\mathrm{Mn}$ & $\mathrm{Si}$ & $\mathrm{Fe}$ & $\mathrm{Cu}$ & $\mathrm{Ni}$ & $\mathrm{Mg}$ \\
\hline Base metal & 9.4 & 0.62 & 0.24 & 0.015 & 0.005 & 0.014 & 0.001 & Bal \\
Welding wire & 6.1 & 1.08 & 0.34 & 0.021 & 0.003 & 0.011 & 0.003 & $\mathrm{Bal}$ \\
\hline
\end{tabular}

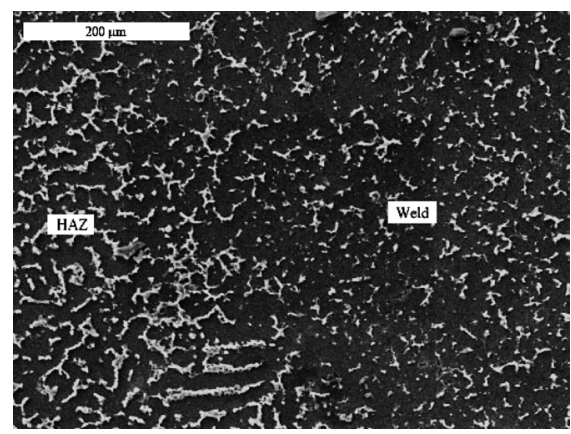

Fig. 1. MIG welded magnesium joint.

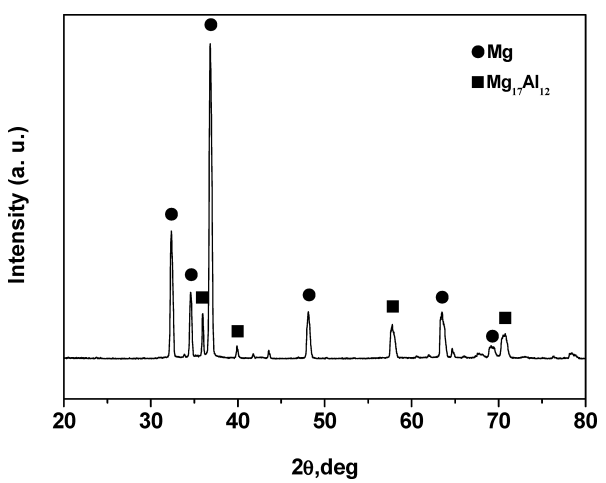

Fig. 2. XRD pattern of magnesium alloy weld.

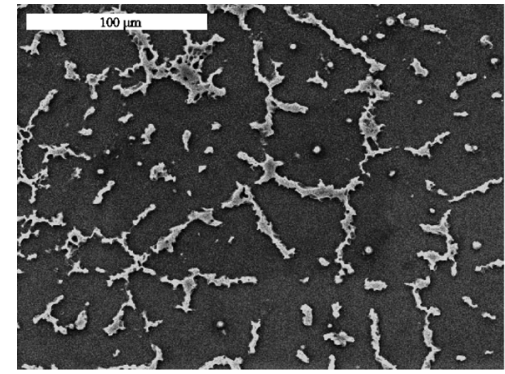

(a)

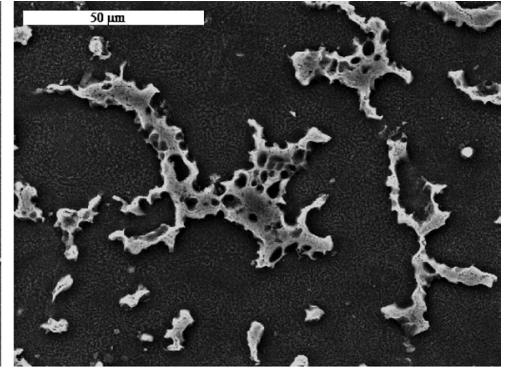

(b)

Fig. 3. The microstructure of weld: (a) microstructure, (b) divorced eutectic morphology.

examined using scanning electron microscopy (SEM) and $\mathrm{X}$-ray diffraction (XRD). The distribution of alloy elements was measured using energy dispersive X-ray spectroscopy (EDS).

\section{Results and Discussion}

\subsection{Microstructure}

MIG welded magnesium alloy joint including weld metal and heat-affected zone (HAZ) is illustrated in Fig. 1. From XRD pattern shown in Fig. 2, it can be seen that the weld with $7.09 \mathrm{wt} \% \mathrm{Al}$ consists of magnesium solid solution $(\alpha$ $\mathrm{Mg})$ and intermetallic compound $\left(\beta-\mathrm{Mg}_{17} \mathrm{Al}_{12}\right)$. Figure 3 shows the microstructure of the weld. As can be seen, the $\beta$ - $\mathrm{Mg}_{17} \mathrm{Al}_{12}$ mainly distributes along $\alpha-\mathrm{Mg}$ grain boundaries (Fig. 3(a)) and the boundary microstructure has a divorced eutectic morphology, which is characterized by 'islands' of eutectic $\alpha$-Mg within the $\beta$-particles, as shown in Fig. 3(b). This is different to the microstructure of discontinues precipitation of $\alpha+\beta$ which are lamellar in appearance. According to the magnesium-aluminum equilibrium phase diagram (Fig. 4), the maximum solid solubility at the eutectic temperature is about $13 \mathrm{wt} \% \mathrm{Al}$, and the eutectic phase $\left(\beta-\mathrm{Mg}_{17} \mathrm{Al}_{12}\right)$ is expected to appear when the $\mathrm{Al}$ content reaches around $13 \mathrm{wt} \%$. However, the eutectic phase appears in the magnesium alloy weld containing $7.09 \mathrm{wt} \%$ $\mathrm{Al}$ for non-equilibrium cooling conditions normally en-

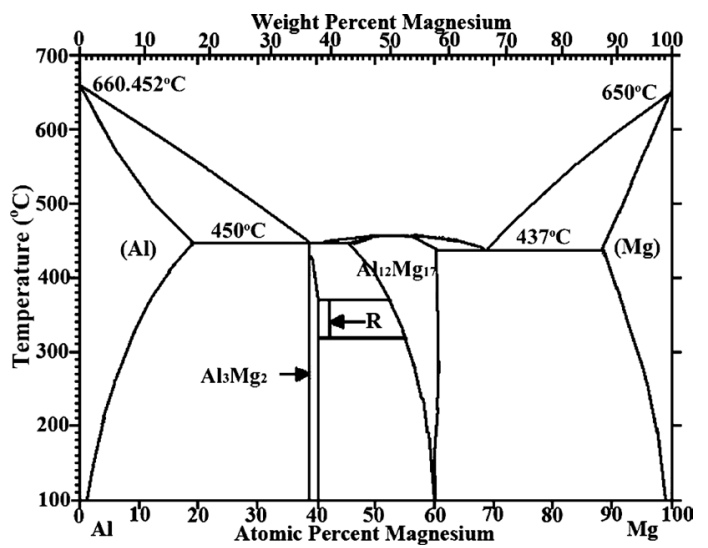

Fig. 4. $\mathrm{Mg}-\mathrm{Al}$ equilibrium phase diagram.

countered in the weld metal. It is well known that the weld molten pool has rapid solidification rate and there is little diffusion in the solid. During solidification of the magnesium alloy weld molten pool, the first $\alpha-\mathrm{Mg}$ grain to form was purer than the liquid from which it formed and the solutes (Al, $\mathrm{Zn}$ and $\mathrm{Mn}$ ) had to be rejected into the liquid. With further solidification, the liquid between $\alpha-\mathrm{Mg}$ grains became progressively richer in $\mathrm{Al}, \mathrm{Zn}$ and $\mathrm{Mn}$. In the final stages of the solidification, the solutes ( $\mathrm{Al}, \mathrm{Zn}$ and $\mathrm{Mn}$ ) were compressed into a comparatively small volume of liquid between $\alpha-\mathrm{Mg}$ grains and solute concentration was thus 
expected to rise rapidly to reach the eutectic composition at the eutectic temperature. During welding, the fast cooling rate tended to move the liquidus, solidus and eutectic point in the $\mathrm{Mg}-\mathrm{Al}$ equilibrium phase diagram to lower temperatures. These solidification characteristics of weld molten pool result in the segregation of $\mathrm{Al}, \mathrm{Zn}$ and $\mathrm{Mn}$ at primary $\alpha-\mathrm{Mg}$ grain boundaries and the formation of the divorced eutectic phases (eutectic $\alpha-\mathrm{Mg}+$ eutectic $\beta-\mathrm{Mg}_{17} \mathrm{Al}_{12}$ ) along the grain boundaries.

During welding of magnesium alloy, HAZ immediately adjacent to the fusion line was heated to the temperature

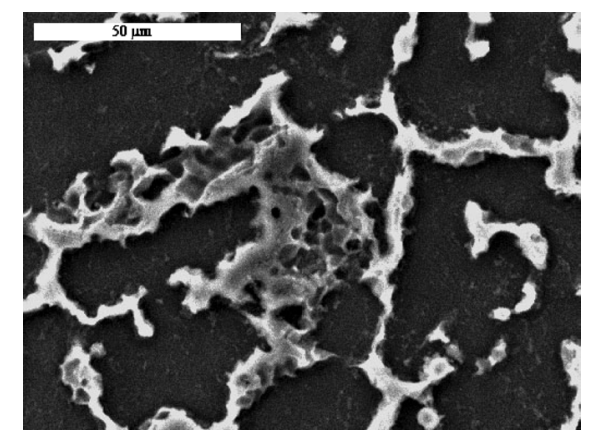

Fig. 5. The microstructure of HAZ.

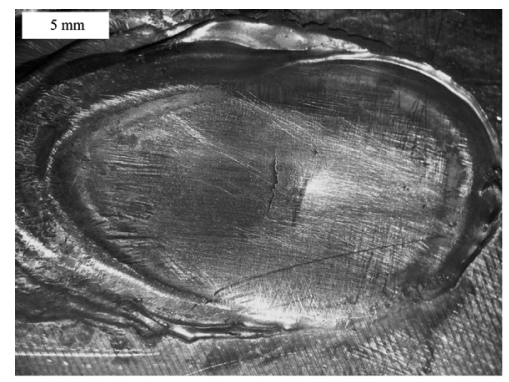

(a) range between the liquidus and eutectic temperature. In this region, part of primary $\alpha-\mathrm{Mg}$ and eutectic phases (eutectic $\alpha-\mathrm{Mg}+$ eutectic $\beta$ - $\mathrm{Mg}_{17} \mathrm{Al}_{12}$ ) at grain boundaries melted, there being a gradual increase in melted boundary width up to the fusion line. The melted portion resolidified through a divorced eutectic reaction resulting in islands of eutectic $\alpha$ $\mathrm{Mg}$ surrounded by the $\beta-\mathrm{Mg}_{17} \mathrm{Al}_{12}$ particles, as shown in Fig. 5.

\subsection{Solidification Cracking}

The experimental results show that the magnesium alloy weld metal has a high cracking susceptibility. Figure 6 shows the appearance of cracks in magnesium alloy welds. The crack often occurred in the crater at the end of a weld (crater cracking) under the conditions of this investigation (welding current of $170 \mathrm{~A}$, welding voltage of $24 \mathrm{~V}$ and welding speeds of $300 \mathrm{~mm} / \mathrm{min}$ and $450 \mathrm{~mm} / \mathrm{min}$ ), as shown in Fig. 6(a). In addition, the crack at the weld centre line (centre line cracking) was also observed when the welding speed was $300 \mathrm{~mm} / \mathrm{min}$ (Fig. 6 (b)). The former is finer than the latter.

In cross section of welded joints, the direction of cracks (crater cracking and centre line cracking) is approximately perpendicular to the weld surface (Figs. 7(a) and 7(b)), and

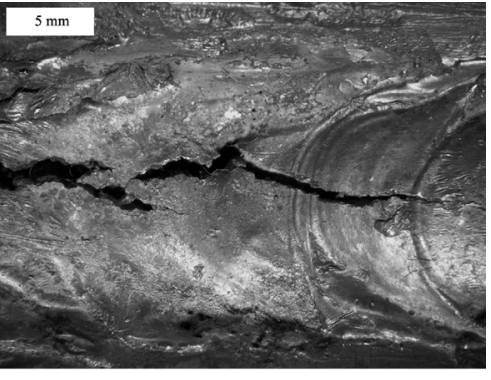

(b)

Fig. 6. The appearance of cracks in welds: (a) crater cracking, (b) centerline cracking.

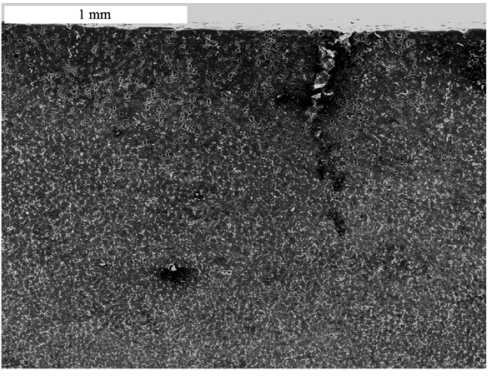

(a)

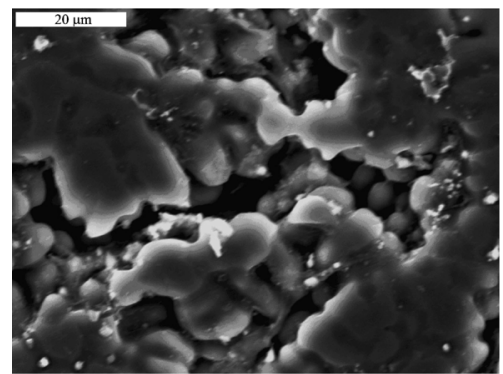

(c)

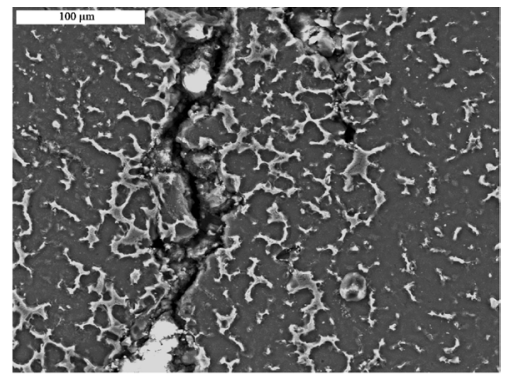

(b)

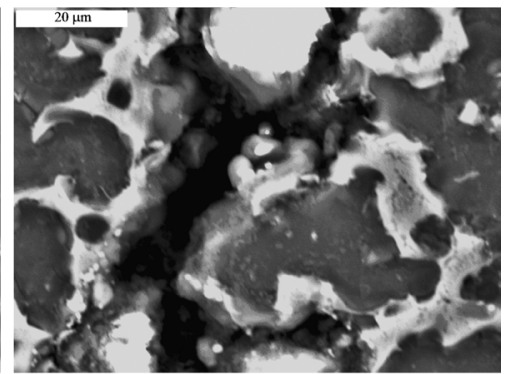

(d)

Fig. 7. The morphology of cracks in cross section of welded joints: (a) crater cracking, (b) centerline cracking, (c) high magnification of (a), (d) high magnification of (b). 


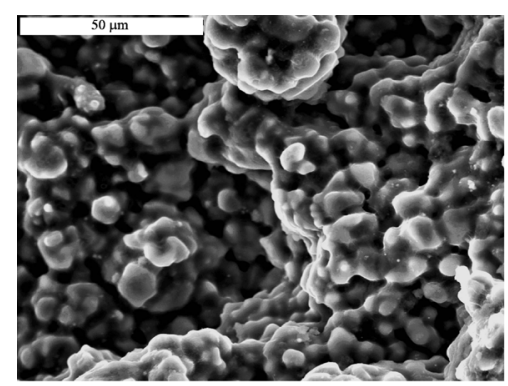

(a)

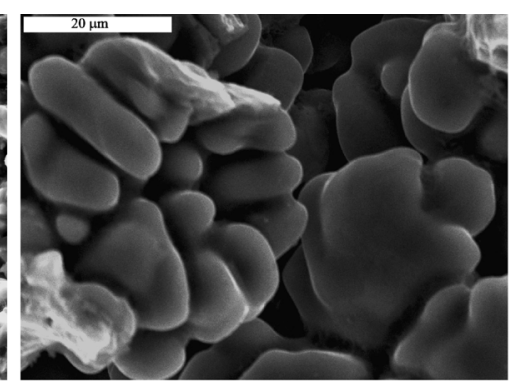

(b)

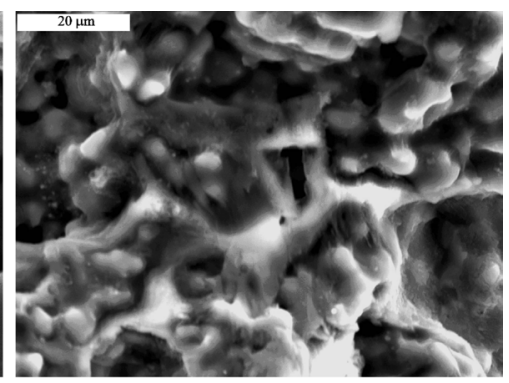

(c)

Fig. 8. SEM opened crack surface morphology: (a) dendritic appearance, (b) dendrite tips, (c) bridges of solid metal.

Table 2. Chemical compositions on the crack surface (wt \%).

\begin{tabular}{lcccccccc}
\hline Element contents & $\mathrm{Al}$ & $\mathrm{Zn}$ & $\mathrm{Mn}$ & $\mathrm{Si}$ & $\mathrm{Fe}$ & $\mathrm{Cu}$ & $\mathrm{Ni}$ & $\mathrm{Mg}$ \\
\hline Average contents & 7.09 & 0.94 & 0.31 & 0.019 & 0.004 & 0.015 & 0.002 & $\mathrm{Bal}$ \\
Metal bridge & 8.95 & 1.06 & 0.89 & 0.020 & 0.004 & 0.017 & 0.003 & $\mathrm{Bal}$ \\
\hline
\end{tabular}

they are interdendritic and usually intergranular with respect to the solidifying grains, as shown in Figs. 7(c) and 7(d). Figure 8 shows SEM opened crack surface morphology. A marked dendritic appearance can be seen clearly and the dendrite tips are rounded, smooth and undamaged (Figs. $8(\mathrm{a})$ and $8(\mathrm{~b})$ ). Sometimes bridges of solid metal are observed on the opened crack surface, which have necked down as the faces of the crack have moved apart, as shown in Fig. 8(c). EDS analysis indicates that the metal bridge $\mathrm{Mn}$ and $\mathrm{Al}$ contents $(0.89 \mathrm{wt} \% \mathrm{Mn}$ and $8.95 \mathrm{wt} \% \mathrm{Al})$ are much higher than the average $\mathrm{Mn}$ and $\mathrm{Al}$ contents in the weld $(0.31 \mathrm{wt} \% \mathrm{Mn}$ and $7.09 \mathrm{wt} \% \mathrm{Al})$ and its $\mathrm{Zn}$ content $(1.06 \mathrm{wt} \% \mathrm{Zn})$ is lightly higher than the average $\mathrm{Zn}$ content $(0.94 \mathrm{wt} \% \mathrm{Zn})$, as presented in Table 2 . The result suggests that there is another particle, $\mathrm{MnAl}_{6}$ in the metal bridge due to increasing $\mathrm{Mn}$ content. Intergranular characteristics of the cracks, dendritic morphology of opened crack surface and segregation of $\mathrm{Mn}, \mathrm{Al}$ and $\mathrm{Zn}$ at the metal bridges suggest that the cracks form during the final stages of solidification and a low melting point liquid film exists between the dendrites at the moment of crack formation. Therefore, the crater cracking and centre line cracking in the magnesium alloy welds should belong to solidification cracking type (hot cracking).

According to the theory about the mechanism of solidification cracking, ${ }^{20)}$ the solidification cracking occurs in brittleness temperature range (BTR) during the solidification of the weld metal. In BTR, low melting point liquid film existing between the grains greatly decreases the strength of weld, so the solidification creaking is more susceptible to this range. When the thermal strain (stress) or strain rate developed during welding surpasses the endurance of the weld metal, the solidification cracking forms in the weld. Metallurgical factor and mechanical factor are always the two main factors causing crack formation. As indicated by Fig. 4, Mg-Al alloys display a wide freezing range, hence a wide BTR for magnesium alloy weld. In the final stages of the weld solidification, the solutes ( $\mathrm{Mn}, \mathrm{Al}$ and $\mathrm{Zn}$ ) segregated in liquid between $\alpha-\mathrm{Mg}$ grains to form low melting point liquid film, decreasing the strength of the weld. On the other hand, magnesium alloys have high thermal expansion coefficient $\left(16.1 \times 10^{-6}{ }^{\circ} \mathrm{C}\right.$ between 20 and $\left.400^{\circ} \mathrm{C}\right)$, so

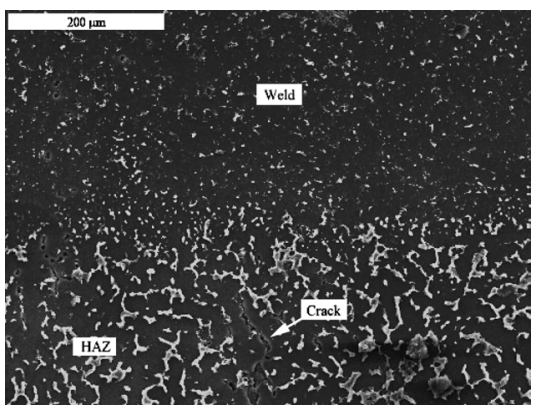

Fig. 9. The crack in HAZ.

the tensile stresses in the magnesium alloy weld are expected to be high. During welding of magnesium alloys, the crater cracking often occurs, because the final crater at the end of the weld has high segregation levels of $\mathrm{Mn}, \mathrm{Al}$ and $\mathrm{Zn}$, and high stress level. The weld centre line cracking at the welding speed of $300 \mathrm{~mm} / \mathrm{min}$ is mainly associated with higher tensile stresses in the weld due to low welding speed resulting in increasing the heat input, hence higher tensile stresses. Therefore, it is favorable to decrease the heat input for improving the susceptibility of solidification cracking in magnesium alloy welds.

\subsection{Liquation Cracking}

In this investigation, it was found that during MIG welding of magnesium alloy the cracks occurred not only in the weld metal but also in HAZ. No crack was observed in HAZ at the welding speed of $450 \mathrm{~mm} / \mathrm{min}$. The crack in HAZ appeared when welding speed was $300 \mathrm{~mm} / \mathrm{min}$. The crack is located in the HAZ immediately adjacent to the fusion line, not propagating into the weld, as shown in Fig. 9. There is a gradual increase in crack width up to the fusion line (Fig. 10). Besides the relatively long crack, some fine cracks were also observed in HAZ near to the fusion line (Fig. 11(a)). As can be seen from Fig. 11(b), the fine cracks are interdendritic and the partial melting occurs at the crack faces. These crack characteristics suggest that the cracks in HAZ form at high temperatures, so it should belong to liquation cracking type (hot cracking). The causes of this type of hot cracking are associated with grain boundary 


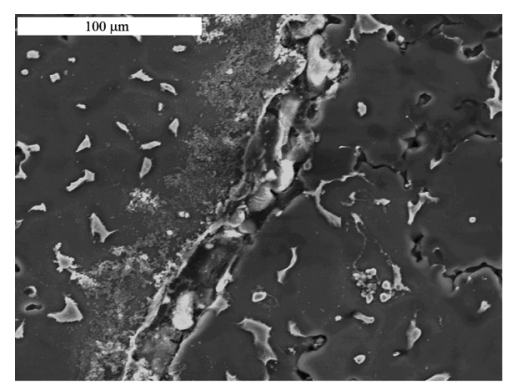

(a)

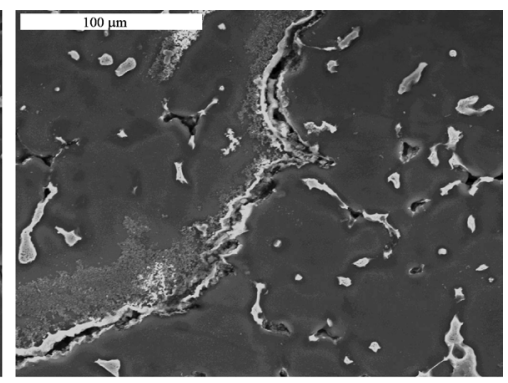

(b)

Fig. 10. The change of crack width in HAZ: (a) crack width near the fusion line, (b) crack width far from the fusion line.

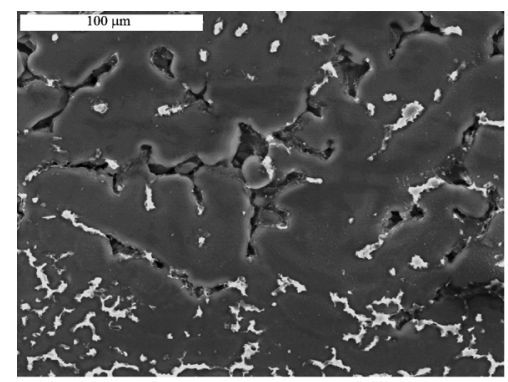

(a)

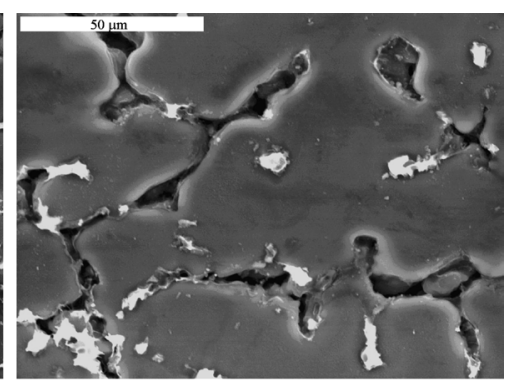

(b)

Fig. 11. Fine cracks in HAZ near the fusion line: (a) fine cracks, (b) high magnification of (a).

segregation aggravated by melting of boundaries near the fusion line. High tensile stresses that occur as the weld cools then tend to rupture these weakened boundaries. ${ }^{21)}$ The liquation cracking formed in magnesium alloy HAZ at the welding speed of $300 \mathrm{~mm} / \mathrm{min}$ is mainly related to the segregation of the solutes ( $\mathrm{Mn}, \mathrm{Al}$ and $\mathrm{Zn}$ ) at grain boundaries and the higher tensile stress due to low welding speed resulting in increasing the heat input. Therefore, it is also favorable to decrease the heat input for improving the susceptibility of liquation cracking in magnesium alloy HAZ.

\section{Conclusions}

(1) Microstructures of MIG welded magnesium alloy (AZ91D) joint consist of primary $\alpha-\mathrm{Mg}$ and divorced eutectic phases (eutectic $\alpha$-Mg+eutectic $\beta$ - $\mathrm{Mg}_{17} \mathrm{Al}_{12}$ ) distributing along the $\alpha$-Mg grain boundaries. It is mainly associated with the fast cooling rate of the joint and the segregation of the solutes ( $\mathrm{Mn}, \mathrm{Al}$ and $\mathrm{Zn}$ ) at the grain boundaries.

(2) During MIG welding of magnesium alloy (AZ91D), the welded joint has a high cracking susceptibility. The cracking in the joint belongs to hot cracking due to forming at high temperatures, including solidification cracking in the weld and liquation cracking in HAZ.

(3) The solidification cracking easily occurs in the crater at the end of a weld, because the crater has high segregation levels of $\mathrm{Mn}, \mathrm{Al}$ and $\mathrm{Zn}$ and high tensile stress level. When low welding speed is used $(300 \mathrm{~mm} / \mathrm{min})$, solidification cracking at welding center line and liquation cracking in HAZ appear, which are mainly related to the low welding speed increasing heat input and tensile stresses. It is favorable to decrease the heat input for improving the susceptibility of hot cracking during MIG welding of magnesium alloys.

\section{Acknowledgements}

The authors would like to thank Changchun and Jilin Province Committees of Science and Technology of China for financial supports.

\section{REFERENCES}

1) S. Lee and D. H. Kim: Metall. Mater. Trans. A, 29A (1998), 1221.

2) B. L. Mordike and T. Ebert: Mater. Sci. Eng., A302 (2001), 37.

3) Y. Uematsu, K. Tokaji and M. Kanakura: Mater. Sci. Eng., A434 (2006), 131 .

4) Y. Tamura, T. Motegi, N. Kono and E. Sato: Mater. Sci. Forum, 350-351 (2000), 199.

5) A. K. Dahle, Y. C. Lee, M. D. Nave, P. L. Schaffer and D. H. StJohn: J. Light Met., 1 (2001), 61.

6) L.-M. Liu, H.-Y. Wang and Z.-D. Zhang: Scr. Mater, 56 (2007), 473.

7) X. Cao, M. Jahazi, J. P. Immarigeon and W. Wallace: J. Mater. Process. Technol., 171 (2006), 188.

8) L. Liu and J. Wang; Mater. Sci. Eng., A381 (2004), 129.

9) A. Kouadri and L. Barrallier: Mater. Sci. Eng., A429 (2006), 11.

10) C.-T. Chi and C.-G. Chao: Mater. Sci. Eng., A435-436 (2006), 672.

11) X. Wang and K. Wang: Mater. Sci. Eng., A431 (2006), 114.

12) D. Q. Sun, D. X. Sun, S. Q. Yin and J. B. Li: ISIJ Int., 46 (2006), 1200 .

13) L. Liu and G. Song: Mater. Sci. Eng., A390 (2005), 76.

14) T. Zhu and Z. W. Chen: Mater. Sci. Eng., A416 (2006), 246.

15) D. Q. Sun, X. Y. Gu and W. H. Liu: Mater. Sci. Eng., A391 (2005), 29.

16) D. Q. Sun, W. H. Liu and X. Y. Gu: Mater. Sci. Technol., 20 (2004), 1595.

17) American Welding Society, Welding Handbook, 7th ed., Vol. 4, AWS, Miami, FL, (1989).

18) D. Q. Sun, B. Lang, D. X. Sun and J. B. Li: Mater. Sci. Eng., A460-461 (2007), 494.

19) W. Zhou, T. Z. Long and C. K. Mark: Mater. Sci.Technol., 23 (2007), 1294.

20) N. N. Prokhorov: Weld. Product., 9 (1962), 1.

21) Kenneth Easterling, Introduction to the Physical Metallurgy of Welding, London Publishing, (1981), 170. 